\title{
Heavy Metals Adsorption by Mixed Liquid Suspended Solids (MLSS)
}

\author{
Rouhallah Mahmoudkhani, Majid Bayatian, and Mohamad Reza Khani
}

\begin{abstract}
One of the important concerns in Tehran municipal landfill is the production of leachate and its potential for water resources pollution. This paper investigates the removal of heavy metals from landfill leachate by using a combined system of a membrane Bioreactor (MBR) together with reverse osmosis. The leachate was collected from a landfill in the vicinity of Tehran nearly 1 year old, The data indicated that the system provided high removals of $\mathrm{Fe}, \mathrm{Ni}, \mathrm{Cu}, \mathrm{Zn}, \mathrm{Pb}, \mathrm{Cd}$ and $\mathrm{Cr}$ equal to $98 \%, 79 \%, 85 \%, 85 \%, 87 \%, 82 \%$, and $73 \%$ respectively and heavy metal concentration in MBR effluent is a function of aeration ratio and bioaccumulation. Among the metals investigated in the present study It can be concluded that the extracellular adsorption, is the principal removal process of the metals, compared to other removal mechanisms such as bioaccumulation or intracellular accumulation, $\mathrm{Cu}, \mathrm{Cr}, \mathrm{Ni}, \mathrm{Pb}$, $\mathrm{Cd}, \mathrm{Zn}$, and $\mathrm{Fe}$, respectively, have higher capability of being adsorbed through biological processes by MLSS. Also, based on Freundlich Isotherm, $\mathrm{Cr}, \mathrm{Cd}, \mathrm{Pb}, \mathrm{Cu}, \mathrm{Zn}$, and $\mathrm{Fe}$, in turn, have the most saturation rate for every gram of MLSS and their maximum fast absorption is $0.000023,0.0035,0.22,5,6,130$ mg/g MLSS, respectively.
\end{abstract}

Index Terms-Adsorption, heavy metals, leachate, MLSS, membrane bioreactor.

\section{INTRODUCTION}

The method of anaerobic sanitary landfill for the disposal of municipal solid wastes continues to be widely used in most countries throughout the world [1]. One of the most important issues of concern in landfill management is the production of landfill leachate and its potential for degrading water resources [2]. Heavy metals constitute one of the pollutant groups that are kept under surveillance in leachate from landfills for municipal solid waste (MSW) [3].

Since 1970s heavy metals have been causing a growing concern over their toxic effects on humans and aquatic ecosystems. In fact biological wastewater treatment systems are mainly designed for organic matter removal and only side-benefit can be observed in the treatment of heavy-metal-bearing streams. Microorganisms of activated sludge can remove heavy metals by different mechanisms, which can be classified according to their dependence or less on the metabolism activity as bioaccumulation and biosorption, respectively [4].

The technologies available for the removal of heavy metals include chemical precipitation, adsorption, ion exchange and

Manuscript received April 15, 2015; revised June 8, 2015.

The authors are with the Department of Health, Tehran Medical Sciences Branch, Islamic Azad University, Tehran, Iran (e-mail: rmahmoudkhani@iautmu.ac.ir,_ majid_bayatian@yahoo.com, khani133958@gmail.com).
Reverse Osmosis. Metal removal in biological treatment processes is mainly by adsorption, this finding indicated that main mechanisms operating in metal removal by activated sludge are metabolism-independent and biosorption mechanisms and Heavy metals have negative impacts on microorganisms and consequently decreasing the effectiveness of biological processes in removing organic matter [5]. The removal of metals in biological processes has been found to fit adsorption characteristics displayed by the Freundlich isotherm model. The Freundlich isotherm is used most commonly to describe the adsorption characteristics [6], the Freundlich isotherm is defined as equation number 1 :

$$
\frac{x}{m}=K_{f} C_{e}^{\frac{1}{n}}
$$

where $x / m$ is the mass of adsorbate adsorbed per unit mass of adsorbent (mg adsorbate/g MLSS), $K_{f}$ is the Freundlich capacity factor $((\mathrm{mg}$ adsorbate/g MLSS $) \times(L$ water $/ \mathrm{mg}$ adsorbate) $1 / n), C_{e}$ is the Equilibrium Concentration of adsorbate in solution after adsorption $(\mathrm{mg} / \mathrm{L})$ and is $1 / n$ is the Freundlich intensity parameter [6].

Using these values ( $\mathrm{Fe}, \mathrm{Ni}, \mathrm{Cu}, \mathrm{Zn}, \mathrm{Pb}, \mathrm{Cd}$, and $\mathrm{Cr}$ ) Removal $\left(\mathrm{Q}_{\mathrm{Me}}, \mathrm{mg} / \mathrm{g}\right.$ VSS $)$ can be calculated by the metal material balances in the reactor by equation number 2 [4]:

$$
F .\left(C_{0}-C\right)=F_{w} . X . Q_{M e}
$$

where $F(L / d)$ and $F_{w}(L / d)$ are the influent and the sludge withdrawal flow-rates, respectively. $C_{0}(\mathrm{mg} / \mathrm{l})$ and $C(\mathrm{mg} / \mathrm{l})$ are influent and residual metal concentrations at steady rate, and $X(\mathrm{~g} / \mathrm{L})$ is the biomass concentration at the end of the aerobic phase in the sludge withdrawal stream [4].

Regarding the above facts, to assess the municipal landfill leachate heavy metals treatability a MBR pilot system was coupled with RO system. The study was focused on the evaluation of the MBR and RO systems influent and effluent and operating under different aeration ratio for defining the absorption rate of metals ( $\mathrm{Fe}, \mathrm{Ni}, \mathrm{Cu}, \mathrm{Zn}, \mathrm{Cd}, \mathrm{Pb}$, and $\mathrm{Cr}$ ) by absorbent (MLSS) and physical treatment system.

\section{MATERIAL AND METHODS}

\section{A. Leachate Feed}

The leachate used in this study was collected from a municipal landfill located in a suburban area of Tehran, Kahrizak. The average composition of solid wastes landfilled at Kahrizak landfill is $72.9 \%$ organic (greens and food 
wastes), $7.25 \%$ paper, $1.91 \%$ glass, $2.34 \%$ metals, $8.4 \%$ plastic, $2.37 \%$ textile, $1.09 \%$ rubbers, $1.27 \%$ wood, and $3.6 \%$ oversize and others [7]. The landfill site has been in operation since 1985 . The age of the landfill for sampling is 1-2 years. The characteristics of the landfill leachate investigated are shown in Table I. The leachate used for this study was young because it contained readily biodegradable organic matter [8].

TABLE I: AVERAGE QUALITY OF LANDFILL LEACHATE USED AS FED

\begin{tabular}{llll}
\hline Parameter & Values & Parameter & Values \\
\hline $\mathbf{C O D}, \mathbf{m g} / \mathbf{L}$ & $68250 \pm 8000$ & $\mathbf{P O}_{\mathbf{4}}-\mathbf{P}, \mathbf{m g} / \mathbf{L}$ & $130 \pm 40$ \\
\hline $\mathbf{B O D}, \mathbf{m g} / \mathbf{L}$ & $44500 \pm 3000$ & $\mathbf{S O}_{\mathbf{4}}, \mathbf{m g} / \mathbf{L}$ & $5500 \pm 300$ \\
\hline $\begin{array}{l}\mathbf{N H}_{\mathbf{3}}+\mathbf{N H}_{\mathbf{4}}-\mathbf{N}, \\
\mathbf{m g} / \mathbf{L}\end{array}$ & $1470 \pm 90$ & $\mathbf{C l}^{-}, \mathbf{m g} / \mathbf{L}$ & $14800 \pm 1000$ \\
\hline $\begin{array}{l}\mathbf{N O}_{\mathbf{3}}+\mathbf{N O}_{\mathbf{2}}-\mathbf{N}, \\
\mathbf{m g} / \mathbf{L}\end{array}$ & $150 \pm 50$ & Turbidity, Ntu & $190 \pm 8.4$ \\
\hline $\mathbf{p H}$ & $6.9 \pm 0.2$ & $\begin{array}{l}\text { Conductivity, } \\
\text { Mmhos/cm }\end{array}$ & $44150 \pm 4500$ \\
\hline
\end{tabular}

\section{B. Process Configuration and System Design}

The investigations were carried out at a laboratory scale in a MBR coupled with RO. The MBR with a working volume of $175 \mathrm{~L}$ was made of Plexiglas. Dissolved oxygen was supplied using 2 fine bubble disc diffusers (Ecoflex $250 \mathrm{Cv}$ ), made by USA Diffuser Tech Co., placed at the bottom of the reactor, producing bubbles of pour size. A blower pump with the capacity of $190 \mathrm{~m}^{3} / \mathrm{h}$ and pressure of $320 \mathrm{mbar}$, supplied system air requirement. The pump also had an adjustable air-control valve. Due to the importance of controlling the timely stages in MBR system, as well as setting feeding, vacuuming, backwashing, and measuring and recording of dissolved oxygen and temperature, A PLC and a computerized system with essential accessories, including control and relay boards, dissolved oxygen and temperature probes, electrical valves and feed pump, were used. The dissolved oxygen (DO) concentration was maintained at 3.2 and $2.3 \mathrm{mg} / \mathrm{L}$ by adjusting the air flow to $4 \mathrm{~m}^{3} / \mathrm{h}(1.03 \mathrm{~kg}$ $\mathrm{O}_{2} / \mathrm{kg}$ COD $)$ and $2 \mathrm{~m}^{3} / \mathrm{h}\left(0.58 \mathrm{~kg} \mathrm{O}_{2} / \mathrm{kg}\right.$ COD $)$ respectively. The level of the water in the bioreactor was controlled by a level-controller and a level-sensor. The concentration of the mixed liquor suspended solids (MLSS) at solid retention time of 55 days, were 6300 and $3800 \mathrm{mg} / \mathrm{L}$, at high aeration ratio $(4$ $\left.\mathrm{m}^{3} / \mathrm{h}\right)$ and low aeration ratio $\left(2 \mathrm{~m}^{3} / \mathrm{h}\right)$, respectively. The sludge was withdrawn continuously with a pump set at different solid retention times (SRTs). Hydraulic retention time (HRT) was controlled for 15 days by a rotary flow meter under the operational condition of invariable membrane flux; the effluent of the bioreactor was connected to an automatic vacuum effluent system directly by a rotary flow meter. In this pilot-plant test, a hollow-fiber polypropylene microfiltration (MF) membrane and Reverse Osmosis system were used with pore size of 0.1 and $0.001 \mu \mathrm{m}$, respectively, the effective surface area of the MF membrane module at $4 \mathrm{~m}^{2}$. Membrane flux was between 0.5 and $0.8 \mathrm{~m}^{3} / \mathrm{d}$. The RO membrane used in the process was a Filmtech TW30-1812-100 Membrane (DOW, USA). The unit was installed at the lab and it was designed to run under a constant operating pressure. Influent characteristics were measured once a week. Determination of COD, BOD5, nitrite, nitrate, ammonium, phosphate, sulfate, $\mathrm{Cl}$-, Conductivity, MLSS, turbidity and The heavy metals in the leachate were determined according to the standard methods, 20th ed. [9] and the concentrations of $\mathrm{Fe}, \mathrm{Ni}, \mathrm{Cu}, \mathrm{Zn}$, $\mathrm{Pb}, \mathrm{Cd}$ and $\mathrm{Cr}$ were measured by using Direct Air-Acetylene Flame Atomic Absorption Spectrometric method.

\section{RESULTS AND DISCUSSION}

\section{A. Removal of $\mathrm{Fe}, \mathrm{Ni}, \mathrm{Cu}, \mathrm{Zn}, \mathrm{Pb}, \mathrm{Cd}$ and $\mathrm{Cr}$ in $\mathrm{MBR}$}

MBR was run for approximately 12 months. In this work the attention was specifically focused on the mechanisms of metals removal on MBR with tow aeration rates and RO units. Fig. 1 shows the efficiencies of these units. The removal efficiencies of heavy metals depended on leachate characteristics, such as pH, ORP, Conductivity, the compositions and concentrations of inorganic ions and organic matter, etc., which made it difficult to recognize their behaviors and assess treatment processes. The presented data indicate that the landfill leachate composition has a significant effect on heavy metal treatability.

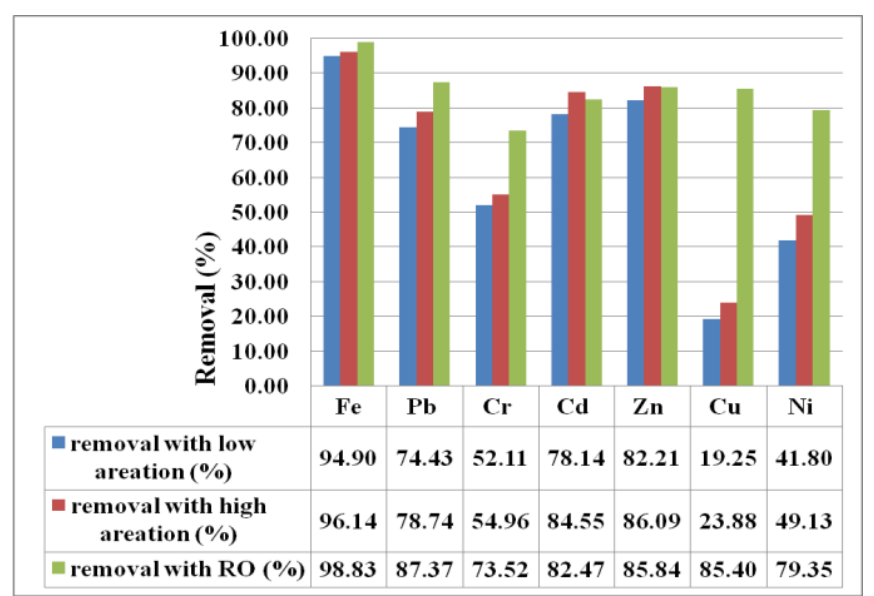

Fig. 1. Heavy metals removal in the MBR outlet with tow aeration ratio and RO.

Although, it is true that the landfill leachate in Iran contains low levels of heavy metals, but it is a misconception to conclude that it is not hazardous, as other complex organic agents may be present. Heavy metal concentration in the MBR effluent is a function of aeration ratio. MBR effluent samples are below the regulation limits in all periods of degradation. Increasing the aeration ratio in membrane bioreactor has a partly positive effect on leachate treatment and heavy metal removal. Increasing the aeration ratio from 2 $\mathrm{m}^{3} / \mathrm{h}$ to $4 \mathrm{~m}^{3} / \mathrm{h}$ causes the rate of heavy metal removal to increase $4.38 \%$ with 2.5 units of standard deviations. Similarly, using reverse osmosis after membrane bioreactor causes the rate of heavy metal removal to increase $19.23 \%$ with 8 units of standard deviations.

The results of the metals adsorption summarized in Table II, the results obtained from Equation 2 and Table II indicate that the rate of the $\mathrm{Cu}, \mathrm{Ni}, \mathrm{Zn}, \mathrm{Fe}, \mathrm{Cd}, \mathrm{Pb}$ and $\mathrm{Cr}$ absorbance with high aeration and with $6.3 \mathrm{~g} / \mathrm{L}$ of MLSS, is equal to 0.26 , $0.501,2.57,21.6,0.242,0.745$ and $0.416 \mathrm{mg} / \mathrm{g}$ MLSS and with low aeration and with $3.8 \mathrm{~g} / \mathrm{L}$ of MLSS is equal to 0.533 , $0.967,4.47,36.2,0.435,1.308$ and $0.728 \mathrm{mg} / \mathrm{g}$ MLSS, respectively. This means that the rate of absorbance at low aeration with less adsorbent substance (MLSS) is almost two times more. The average outlet concentration at higher 
MLSSs is less. These results show that the main metals surface-removal mechanism is based on a combination of physical and chemical mechanisms such as ionic exchange and surface micro precipitation reaction involving a large variety of binding sites of extracellular polymeric substances and bacterial cell surfaces. The same results also indicate that the removal of heavy metals has little connection with intracellular accumulation mechanism, because with decreasing adsorbent cells (MLSS) adsorption does not show significant reduction.

TABLE II: METALS ADSORPTION RATE AND CONCENTRATIONS IN THE MBR INLET AND OUTLET

\begin{tabular}{|c|c|c|c|c|c|c|c|c|}
\hline metals & & $\mathrm{Fe}$ & $\mathrm{Pb}$ & $\mathrm{Cr}$ & $\mathrm{Cd}$ & $\mathrm{Zn}$ & $\mathrm{Cu}$ & $\mathrm{Ni}$ \\
\hline \multirow[t]{2}{*}{ Influent } & average $(\mathrm{mg} / \mathrm{L})$ & 35.85 & 1.587 & 1.261 & 0.489 & 4.940 & 2.146 & 1.86 \\
\hline & standard deviation & 6.854 & 0.455 & 0.176 & 0.498 & 2.80 & 1.796 & 0.439 \\
\hline \multirow[t]{2}{*}{ Effluent with high aeration } & average $(\mathrm{mg} / \mathrm{L})$ & 1.383 & 0.337 & 0.568 & 0.075 & 0.687 & 1.633 & 0.941 \\
\hline & standard deviation & 0.115 & 0.192 & 0.164 & 0.022 & 0.124 & 0.426 & 0.232 \\
\hline \multirow[t]{2}{*}{ Effluent with low aeration } & average $(\mathrm{mg} / \mathrm{L})$ & 1.828 & 0.406 & 0.604 & 0.107 & 0.878 & 1.733 & 1.076 \\
\hline & standard deviation & 0.152 & 0.319 & 0.173 & 0.015 & 0.181 & 1.460 & 0.423 \\
\hline \multirow[t]{2}{*}{$\mathrm{Q}_{\mathrm{Me}}(\mathrm{mg} / \mathrm{gMLSS})$} & High aeration & 21.60 & 0.745 & 0.416 & 0.242 & 2.579 & 0.260 & 0.501 \\
\hline & low aeration & 36.28 & 1.308 & 0.728 & 0.435 & 4.476 & 0.533 & 0.967 \\
\hline
\end{tabular}

TABLE III: FREUNDLICH ADSORPTION ISOTHERM PARAMETERS

\begin{tabular}{|c|c|c|c|c|c|c|c|c|}
\hline metals & & $\mathrm{Fe}$ & $\mathrm{Pb}$ & $\mathrm{Cr}$ & $\mathrm{Cd}$ & $\mathrm{Zn}$ & $\mathrm{Cu}$ & $\mathrm{Ni}$ \\
\hline$x$ & High aeration & 0.0656 & $2.3 \times 10^{-3}$ & $1.3 \times 10^{-3}$ & $7.88 \times 10^{-4}$ & $8.1 \times 10^{-3}$ & $8.883 \times 10^{-4}$ & $1.73 \times 10^{-3}$ \\
\hline$m$ & Low aeration & 0.1169 & $3.7 \times 10^{-3}$ & $2.1 \times 10^{-3}$ & $1.2 \times 10^{-3}$ & 0.0128 & $1.15 \times 10^{-3}$ & $2.41 \times 10^{-3}$ \\
\hline \multirow{2}{*}{$C_{e}$} & High aeration & 1.38 & 0.3376 & 0.568 & 0.0756 & 0.6874 & 0.6336 & 0.941 \\
\hline & Low aeration & 1.82 & 0.406 & 0.604 & 0.107 & 0.8786 & 1.733 & 1.0766 \\
\hline & $k$ & 0.179 & $3.1 \times 10^{-5}$ & $2.8 \times 10^{-8}$ & $6.42 \times 10^{-6}$ & $6.1 \times 10^{-3}$ & $5.6 \times 10^{-3}$ & $2.08 \times 10^{-3}$ \\
\hline & $\frac{1}{n}$ & $6.9 \times 10^{-2}$ & $7.4 \times 10^{-2}$ & $5.2 \times 10^{-2}$ & 0.145 & $4.3 \times 10^{-3}$ & $2.5 \times 10^{-2}$ & $-2.88 \times 10^{-4}$ \\
\hline
\end{tabular}

TABLE IV: METAL REMOVAL RATE AND CONCENTRATIONS IN THE RO INLET AND OUTLET

\begin{tabular}{|c|c|c|c|c|c|c|c|c|}
\hline & metals & $\mathbf{F e}$ & $\mathbf{P b}$ & $\mathrm{Cr}$ & Cd & Zn & $\mathbf{C u}$ & $\mathbf{N i}$ \\
\hline \multirow[t]{2}{*}{ RO Influent } & average $(\mathrm{mg} / \mathrm{L})$ & 1.3834 & 0.3376 & 0.568 & 0.0756 & 0.6874 & 1.6336 & 0.941 \\
\hline & standard deviation & 0.116 & 0.193 & 0.164 & 0.023 & 0.125 & 0.427 & 0.233 \\
\hline \multirow[t]{2}{*}{ RO Effluent } & average $(\mathrm{mg} / \mathrm{L})$ & 0.4162 & 0.2006 & 0.334 & 0.0758 & 0.6996 & 0.3134 & 0.382 \\
\hline & standard deviation & 0.138 & 0.084 & 0.063 & 0.030 & 0.189 & 0.114 & 0.233 \\
\hline removal & Percent $(\%)$ & 69.91 & 40.58 & 41.20 & 0 & 0 & 80.82 & 59.40 \\
\hline
\end{tabular}

Determining the ratio of adsorbate to absorbent and metals equilibrium concentration at different concentrations of MLSS and using all the data in Freundlich Isotherm Equation, leaded to determining the concentration equilibrium changes, and the absorbent substance specification that are estimated through Table III.

After plotting the isotherm, as it is clear in the Fig. 2, the maximum rate of $\mathrm{Cr}, \mathrm{Cd}, \mathrm{Pb}, \mathrm{Cu}, \mathrm{Zn}$, and $\mathrm{Fe}$ adsorbed by the adsorbent (MLSS), in the biological process, is 0.000023, $0.0035,0.22,5,6,130 \mathrm{mg} / \mathrm{g}$ MLSS, respectively. It is then that the metals concentration equilibrium increases in the system.

\section{B. Removal of $\mathrm{Fe}, \mathrm{Ni}, \mathrm{Cu}, \mathrm{Zn}, \mathrm{Pb}, \mathrm{Cd}$ and $\mathrm{Cr}$ by $\mathrm{RO}$}

In the work of Li et al., In new landfill leachate, the percentages of truly-dissolved $\mathrm{As}, \mathrm{Cr}, \mathrm{Pb}$ and $\mathrm{Zn}$ were $26 \%$, $59 \%, 29 \%$ and $55 \%$ respectively. In row leachate $\mathrm{Cu}$ and $\mathrm{Ni}$ were fully colloidal [5]. In mature landfill, the percentage of truly-dissolved $\mathrm{As}, \mathrm{Cr}, \mathrm{Cu}, \mathrm{Pb}$ and $\mathrm{Zn}$ were $46 \%, 25 \%, 37 \%$, $88 \%$ and $47 \%$ respectively, and $\mathrm{Ni}$ was fully colloidal in raw leachate. After MBR treatment, there were higher proportions of truly-dissolved $\mathrm{As}, \mathrm{Ni}, \mathrm{Pb}, \mathrm{Zn}$ and lower proportions of fully-dissolved $\mathrm{Cr}$ and $\mathrm{Cu}$ [5]. In new landfill leachate, $\mathrm{Cr}$ and
Zn existed primarily in the truly-dissolved fraction, while As and $\mathrm{Pb}$ existed primarily in the colloidal fraction. In mature landfill leachates, $\mathrm{As}$ and $\mathrm{Zn}$ existed primarily in the truly-dissolved fraction, but $\mathrm{Cr}$ and $\mathrm{Ni}$ existed primarily in the colloidal fraction. Only the size fraction of $\mathrm{Zn}$ had similar characteristics in new and mature landfill leachates throughout the treatment processes [5].

In this regard, Oygarda et al., who examined the size fraction of heavy metals, showed that $\mathrm{Cd}$ and $\mathrm{Zn}$, and especially $\mathrm{Cu}$ and $\mathrm{Pb}$, were present to large degree (63-98\%) as particulate and colloidal matter $>0.45 \mu \mathrm{m}$ and the fraction under $0.45 \mu \mathrm{m}$ (dissolved) accounted for only $1-13 \%$ of $\mathrm{Pb}$ and $5-30 \%$ of $\mathrm{Cu}$. $\mathrm{Zn}$ and $\mathrm{Cd}$ were also present to a large extent in the $>0.45 \mu \mathrm{m}$ fraction. However, at some of the landfills up to $50 \%$ of $\mathrm{Zn}$ and $75 \%$ of $\mathrm{Cd}$ was present in the dissolved fraction. On average, $20 \%$ of $\mathrm{Zn}$ and $30 \%$ of $\mathrm{Cd}$ was present in the dissolved fraction. On average $18 \pm 18 \%$ of $\mathrm{Cd}$ and $8 \pm 8 \%$ of $\mathrm{Zn}$ was present as free cations or labile complexes. $\mathrm{Cr}$, Co and $\mathrm{Ni}$ were on the contrary present mostly as non-labile complexes $(69-79 \%)<0.45 \mu \mathrm{m}$ [3].

The behavior of the $\mathrm{Ni}, \mathrm{Cu}$, and $\mathrm{Cr}$, were slightly different from other heavy metals. The average percentage removal of $\mathrm{Ni}, \mathrm{Cu}$, and $\mathrm{Cr}$ in MBR were $49.13 \%, 23.88 \%$ and $54.96 \%$, 
respectively. This was the lowest removal observed of all heavy metals. The presence of $\mathrm{Cu}$ in the outlet of the MBR system indicated that copper was in soluble ionic or complex form and the presence of $\mathrm{Ni}$ and $\mathrm{Cr}$ in the same outlet indicated that $\mathrm{Ni}$ and $\mathrm{Cr}$ existed primarily in the truly-dissolved fraction. The inspection of Fig. 1 indicates that about $85.4 \%$ and $23.88 \%$ of the initial load of $\mathrm{Cu}, 79.35 \%$ and $49.13 \%$ of the initial load of $\mathrm{Ni}, 85.84 \%$ and $86.09 \%$ of the initial load of $\mathrm{Zn}, 98.83 \%$ and $96.14 \%$ of the initial load of $\mathrm{Fe}, 82.47 \%$ and $84.55 \%$ of the initial load of $\mathrm{Cd}, 87.37 \%$ and $78.74 \%$ of the initial load of $\mathrm{Pb}$ and $73.52 \%$ and $54.96 \%$ of the initial load of $\mathrm{Cr}$ can be removed by RO and MBR with high aeration, respectively. About $15 \%$ of $\mathrm{Cu}, 21 \%$ of $\mathrm{Ni}$, $14 \%$ of $\mathrm{Zn}, 1 \%$ of $\mathrm{Fe}, 17 \%$ of $\mathrm{Cd}, 12 \%$ of $\mathrm{Pb}$ and $27 \%$ of $\mathrm{Cr}$ cannot be removed by RO $(<0.001 \mu \mathrm{m})$. These results show that perhaps about $15 \%$ of $\mathrm{Cu}, 21 \%$ of $\mathrm{Ni}, 14 \%$ of $\mathrm{Zn}, 1 \%$ of $\mathrm{Fe}, 17 \%$ of $\mathrm{Cd}, 12 \%$ of $\mathrm{Pb}$ and $27 \%$ of $\mathrm{Cr}$ were present in the dissolved fraction. The average MBR percentage removal of $\mathrm{Cu}$ was $23.88 \%$. This was the lowest removal observed of all heavy metals. The presence of $\mathrm{Cu}$ in the outlet of the MBR system indicated that copper was in soluble ionic or complex form [10]. The metal removals were extremely high: $\mathrm{Fe}, \mathrm{Pb}$, $\mathrm{Zn}$ and $\mathrm{Cd}$ were removed by $98.83 \%, 87.37 \%, 85.84 \%$ and $82.47 \%$ indicating that these four metals were in particulate form, while $\mathrm{Cr}, \mathrm{Ni}$, and $\mathrm{Cu}$ were removed by $73.52 \%, 79.35 \%$ and $85.4 \%$, respectively.
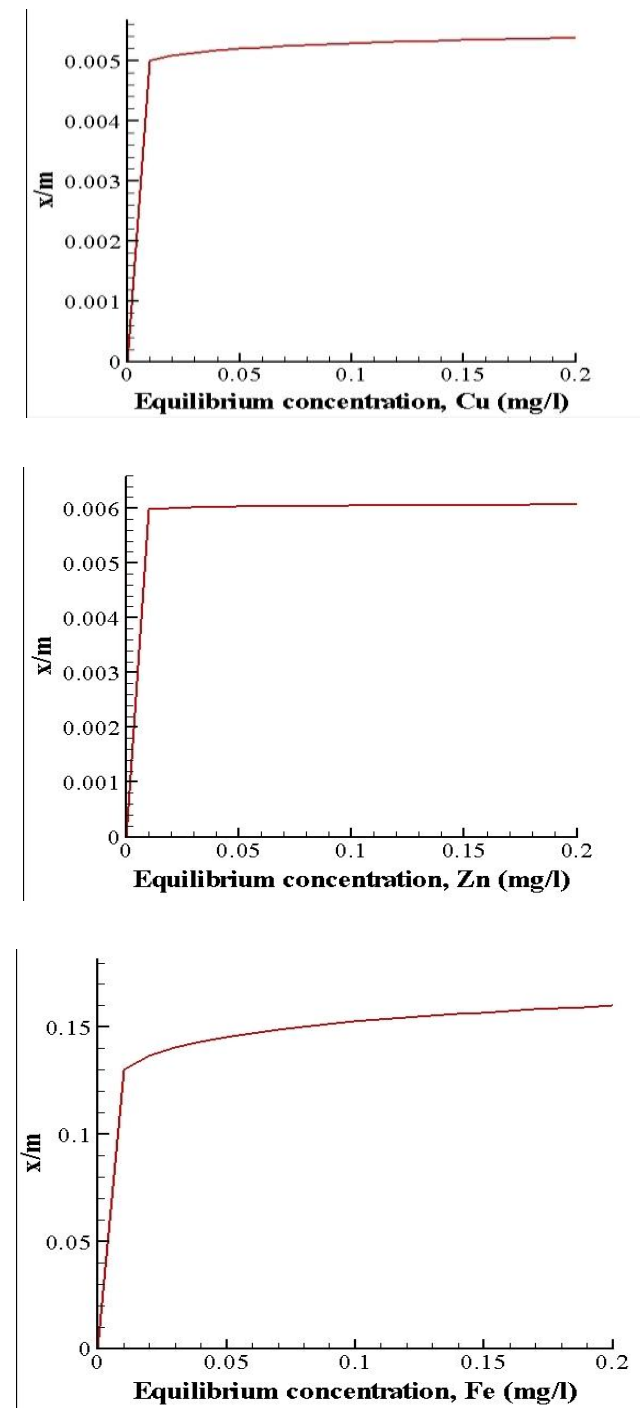
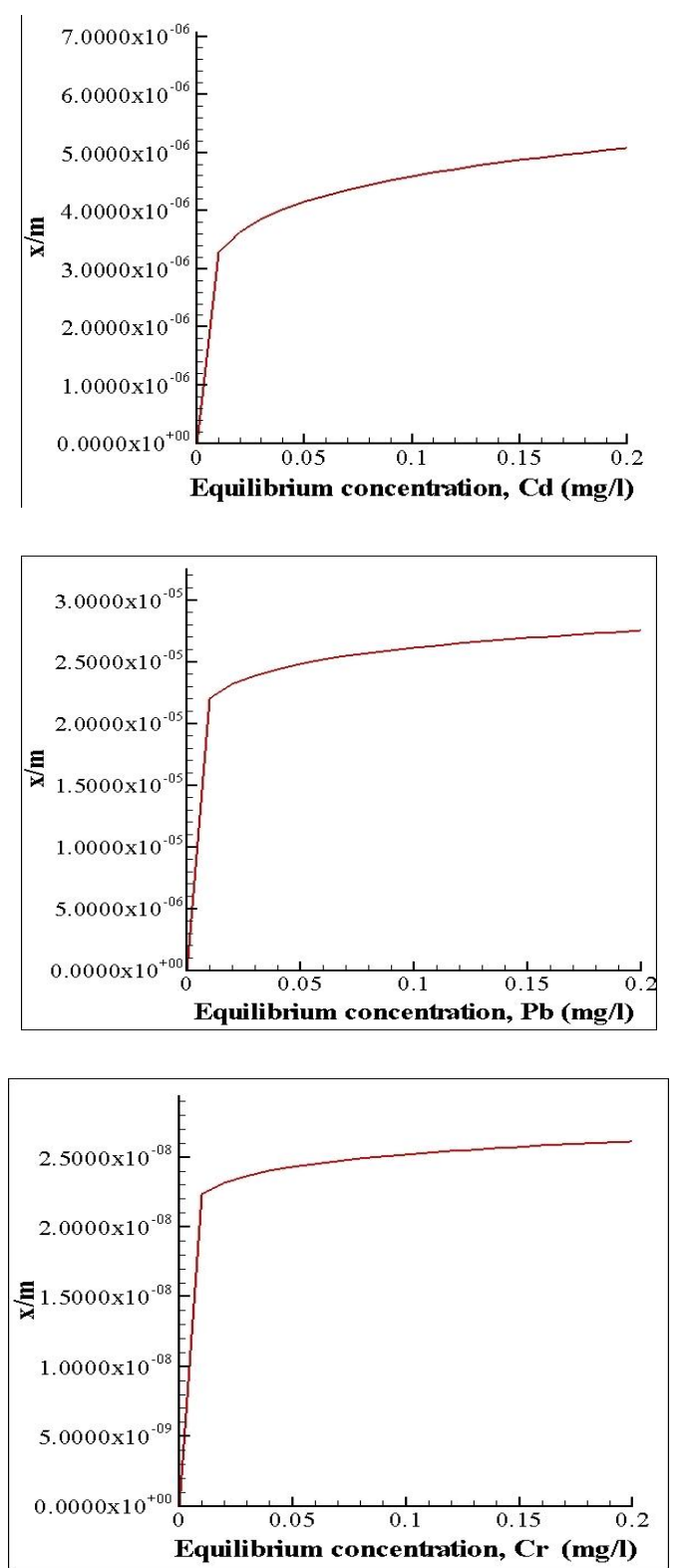

Fig. 2. Relation between metals equilibrium concentration $(\mathrm{mg} / \mathrm{l})$ and $\mathrm{X} / \mathrm{M}$ (mg adsorbate/mg MLSS).

The results of the MBR effluent metals removal by RO summarized in Table IV, the results indicate that the rate of the $\mathrm{Cu}, \mathrm{Fe}, \mathrm{Ni}, \mathrm{Cr}$ and $\mathrm{Pb}$ removal in $\mathrm{RO}$ is equal to $80.4 \%$, $69.9 \%, 59.4 \%, 41.2 \%$ and $40.5 \%$, respectively and RO had no effect on $\mathrm{Cd}$ and $\mathrm{Zn}$ removal.

\section{CONCLUSIONS}

The results indicate that the rate of heavy-metal removal is rather constant and an increase in the concentrations of inletmetals, just at certain ratios of the absorbent to adsorbate substances, adds to the removal rate in a progressive manner. Regarding the fact that the concentration of heavy metals in the leachate of the urban wastes is low, applying the biological method for the removal of metals from the leachate in the landfills of the developing countries, can be an effective method.

Among the metals investigated in the present study, $\mathrm{Cu}, \mathrm{Ni}$, $\mathrm{Cr}, \mathrm{Pb}, \mathrm{Cd}, \mathrm{Zn}$, and $\mathrm{Fe}$, respectively, have higher capability of being adsorbed through biological processes by MLSS. Also, based on Freundlich Isotherm, $\mathrm{Cr}, \mathrm{Cd}, \mathrm{Pb}, \mathrm{Cu}, \mathrm{Zn}$, and $\mathrm{Fe}$, in 
turn, have the most saturation rate for every gram of MLSS and their maximum fast absorption is $0.000023,0.0035,0.22$, $5,6,130 \mathrm{mg} / \mathrm{g}$ MLSS, respectively.

\section{REFERENCES}

[1] M. S. Bilgili, A. Demir, E. Akkaya, and B.Ozkaya, "COD fractions of leachate from aerobic and anaerobic pilot scale landfill reactors," Journal of Hazardous Materials, vol. 158, pp. 157-163, 2008.

[2] S. Kheradmand, A. Karimi-Jashni, and M. Sartaj, "Treatment of municipal landfill leachate using a combined anaerobic digester and activated sludge system," Waste Management, vol. 30, pp. 1025-1031, 2010 .

[3] J. K. Oygarda, E. Gjengedala, and O. Roysetb, "Size charge fractionation of metals in municipal solid waste landfill leachate," Water Research, vol. 41, pp. 47-54, 2007.

[4] F. Pagnanelli, S. Mainelli, L. Bornoroni, and D. Dionisi, "Mechanisms of heavy-metal removal by activated sludge," Chemosphere, vol. 75, pp. 1028-1034, 2009.

[5] R. Li, D. Yue, J. Liu, and Y. Nie, "Size fractionation of organic matter and heavy metals in raw and treated leachate," Waste Management, vol. 29, pp. 2527-2533, 2009.

[6] G. Tchobanoglous, F. L. Burton, and H. D. Stensel, Wastewater Engineering Treatment and Reuse, Fourth Edition, Metcalf \& Eddy, inc., 2003
[7] R. Mahmoudkhani, B. Valizadeh, and H. Khastoo, "Greenhouse gases life cycle assessment (GHGLCA) as a decision support tool for municipal solid waste management in Iran," Journal of Environmental Health Science \& Engineering , vol. 12, p. 71, 2014.

[8] H. Hasar, S. A. Unsal, U. Ipek, S. Karatas, O. Cinar, C. Yaman, and C Kınac, " Stripping/flocculation/membrane bioreactor/reverse osmosis treatment of municipal landfill leachate," Journal of Hazardous Materials, vol. 171, pp. 309- 317, 2009.

[9] Standard Methods for the Examination of Water and Wastewater, 20th ed., American Public Health Association (APHA), Washington, DC, USA. 1998

[10] E. Dialynas and E. Diamadopoulos, "Integration of membrane bioreactor coupled with reverse osmosis for advanced treatment of municipal wastewater," Desalination, vol. 238, pp. 302- 311, 2009.

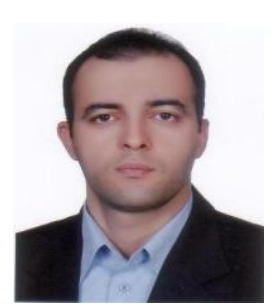

Rouhallah Mahmoudkhani is an assistant professor of the Department of Health, Tehran Medical Sciences Branch, Islamic Azad University, Tehran, Iran, His researches include landfill leachate and biogas generation, membrane bioreactors application and municipal waste management. He is currently an expert of urban environment and waste management in interior ministry. 